\title{
Kadar Lemak dan Protein Karkas Ayam Broiler Akibat Penggunaan Tepung Limbah Wortel (Daucus carota L.) dalam Ransum
}

\author{
Fat and Protein Contents of Carcass Broiler due to the Use of Waste Carrot Meal in the Diet
}

\author{
N. A. Azizah, L. D. Mahfudz dan D. Sunarti \\ Fakultas Peternakan dan Pertanian Universitas Diponegoro \\ Tembalang 50275, Semarang, Indonesia \\ Koresponden e-mail : azizahnuristi@gmail.com
}

\begin{abstract}
This study was to examine the effect of waste product of carrot (Daucus carota. L) meal on carcass quality of broiler chicken (fat and protein of meat content and pigmentation of carcass skin). The material used were one

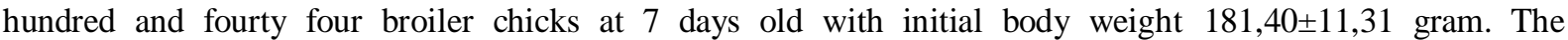
experimental design was completely randomized design with 4 treatments and 6 replications, each unit consisted of 6 broilers. The treatments were T1 (control), T2 (diet with 2\% carrot meal), T3 (diet with 4\% carrot meal), T4 (diet with $6 \%$ carrot meal). The experiment ration was offered to the chicken for four weeks. Variable measured were fat and protein of meat content and pigmentation of carcass skin. The result showed that the treatments did not affect to meat fat content and pigmentation of carcass skin, while the carcass protein content was significantly decreased. In conclusion, the use of carrot meal in the diet can activate calcium activated neutral protease (CANP) enzymes and decreased of protein carcass.
\end{abstract}

Key words : broiler, carrot meal, fat and protein carcass, carcass pigmentation.

\begin{abstract}
ABSTRAK
Penelitian bertujuan untuk mengkaji efek pemberian tepung limbah wortel pada kualitas karkas ayam broiler (lemak dan protein karkas, pigmentasi kulit karkas). Materi yang digunakan yaitu 144 ayam broiler umur 7 hari

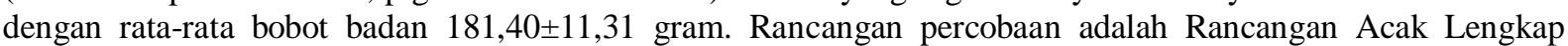
(RAL) dengan 4 perlakuan dan 6 ulangan, setiap ulangan terdiri dari 6 ekor broiler. Perlakuan yaitu T1 (kontrol), T2 (ransum dengan $2 \%$ tepung wortel), T3 (ransum dengan $4 \%$ tepung wortel), T4 (ransum dengan $6 \%$ tepung wortel). Penelitian dilakukan selama 4 minggu. Variabel yang diamati antara lain lemak dan protein karkas, pigmentasi kulit karkas. Hasil menunjukan perlakuan tidak memberikan pengaruh nyata pada lemak karkas dan pigmentasi kulit karkas, namun perlakuan secara nyata menurunkan protein karkas. Disimpulkan penggunaan tepung wortel dalam ransum dapat mengaktifkan enzim calcium activated neutral protease (CANP) dan menurunkan protein karkas.
\end{abstract}

Kata kunci : broiler, tepung wortel, lemak dan protein karkas, pigmentasi karkas.

\section{PENDAHULUAN}

Ayam broiler merupakan salah satu ternak unggas yang secara genetik sebagai penghasil daging yang cukup potensial. Kelebihan ayam broiler yaitu pertumbuhannya yang cepat dan efisien dalam memanfaatkan pakan serta harga produk yang relatif terjangkau, membuat peminat ayam broiler cukup tinggi. Namun, pertumbuhan ayam broiler yang cepat diikuti oleh pertumbuhan lemak, dimana bobot badan yang tinggi berhubungan dengan penimbunan lemak tubuh yang tinggi pula. Kandungan lemak dalam karkas yang tinggi menjadi perhatian khusus bagi konsumen dan produsen ternak.

Karkas yang baik adalah karkas yang mengandung daging dengan kadar lemak rendah dan kandungan protein tinggi, dimana hal tersebut sangat dipengaruhi oleh pakan dan pengelolaan. Selain dari 
komponen kimia karkas, kualitas karkas juga ditentukan dari penampilan fisik karkas, salah satunya yaitu pigmentasi warna karkas. Konsumen cenderung lebih menyukai karkas dengan kulit warna kuning dan perdagingan yang baik daripada warna karkas yang pucat dan daging bertekstur lembek. Manajemen pemberian pakan dengan menggunakan bahan pakan yang mengandung vitamin dan mineral yang baik diharapkan dapat meningkatkan kualitas karkas (Asmara et al., 2007).

Upaya untuk meningkatkan kualitas karkas dapat dilakukan dengan pemberian bahan pakan yang mengandung vitamin dan mineral. Vitamin $\mathrm{C}$ dan $\mathrm{E}$ dapat berperan sebagai antioksidan. Antioksidan alami dapat diperoleh dari limbah umbi wortel yang dapat dimanfaatkan sebagai bahan pakan alternatif penyusun ransum ayam broiler. Limbah umbi wortel merupakan tanaman sayuran umbi yang kaya antioksidan beta karoten yang merupakan prekursor vitamin $\mathrm{A}$, serta mengandung cukup banyak tiamin dan riboflavin. Selain itu, limbah umbi wortel juga mengandung cukup mineral dan vitamin C (Asgar dan Musaddad, 2006).

Vitamin $C$ yang terdapat dalam wortel berperan sebagai antioksidan sekunder yang akan efektif bekerja bilamana disertai dengan adanya antioksidan primer seperti vitamin E. Antioksidan primer bekerja dengan mengubah radikal-radikal lipid menjadi produk yang lebih stabil. Menurut Lestari (2011) pemberian vitamin C dapat menghasilkan karkas yang tidak mudah mengalami penyusutan sehingga kualitas karkas terjaga. Selain itu vitamin $\mathrm{C}$ juga dapat mencegah katabolisme protein.

Tingginya kandungan beta karoten dalam wortel dapat berperan sebagai pigmen alami yang dapat meningkatkan pigmentasi warna karkas. Wortel memiliki kandungan vitamin $\mathrm{E}$ yang bermanfaat sebagai antioksidan dan berfungsi melindungi asam-asam lemak dan kolesterol dari oksidasi dengan cara menangkap radikal-radikal bebas. Menurut Lestari (2011) vitamin E memiliki pengaruh terhadap penurunan oksidasi lipid di dalam daging dan jaringan adipose ternak. Pengontrolan terhadap oksidasi lipid dalam daging akan mempertahankan kualitas daging.

Tujuan dari penelitian ini yaitu untuk mengkaji ada atau tidaknya pengaruh penggunaan tepung wortel pada ransum terhadap kualitas karkas ayam broiler yang meliputi kadar lemak karkas, protein karkas dan pigmentasi warna karkas.

\section{MATERI DAN METODE}

Materi yang digunakan dalam penelitian meliputi ayam broiler strain Lohmann unsex berumur 7 hari sebanyak 144 ekor dengan bobot badan awal ratarata $181,40 \pm 11,31 \mathrm{~g}$. Pemeliharaan ayam broiler dilakukan selama 35 hari dengan menggunakan ransum perlakuan periode starter dan periode finisher. Ransum perlakuan meliputi jagung kuning, bekatul, tepung ikan, PMM (Poultry Meat Meal), Bungkil Kedelai, MBM (Meat Bone Meal), Tepung wortel, dan premix. Limbah wortel yang digunakan yaitu bagian umbi wortel dengan kriteria tidak busuk dan tidak terlalu tua yang tidak lolos sortir. Kandungan bahan pakan ransum dapat dilihat pada Tabel 1. Komposisi dan kandungan nutrisi ransum perlakuan periode starter dan finisher disajikan pada Tabel 2 dan 3. 
Tabel 1. Kandungan Nutrisi Bahan Pakan Ransum

\begin{tabular}{|c|c|c|c|c|c|c|}
\hline Bahan Pakan & EM & PK & SK & LK & $\mathrm{Ca}$ & $\mathrm{P}$ \\
\hline & $\mathrm{Kkal} / \mathrm{Kg}$ & ------- & ------- & $\%$ \%----- & ---- & \\
\hline Jagung Kuning & $3.280,81$ & 7,55 & 8,33 & 2,26 & 0,03 & 0,01 \\
\hline Bekatul & 2546,95 & 11,61 & 26,70 & 7,50 & 0,01 & 1,69 \\
\hline Tepung Ikan & 3131,05 & 54,02 & 0,50 & 7,76 & 7,06 & 2,50 \\
\hline Poultry Meat Meal & 3232,56 & 57,90 & 9,72 & 12,13 & 1,01 & 2,24 \\
\hline Bungkil Kedelai & 2995,43 & 47,53 & 7,60 & 0,51 & 0,05 & 0,69 \\
\hline Meat Bone Meal & 2673,66 & 47,84 & 3,62 & 7,11 & 10,3 & 5,10 \\
\hline Tepung Wortel & 2487,12 & 9,27 & 19,64 & 1,2 & 0,06 & 0,52 \\
\hline Premix & 0,00 & 0,00 & 0,00 & 0,00 & 2,79 & 0,51 \\
\hline
\end{tabular}

Sumber : Analisis Laboratorium Ilmu Nutrisi dan Pakan Universitas Diponegoro, 2016

Tabel 2. Komposisi dan Kandungan Nutrisi Ransum Perlakuan Fase Starter

\begin{tabular}{|c|c|c|c|c|}
\hline Bahan pakan & T0 & $\mathrm{T} 1$ & $\mathrm{~T} 2$ & $\mathrm{~T} 3$ \\
\hline & \multicolumn{4}{|c|}{ 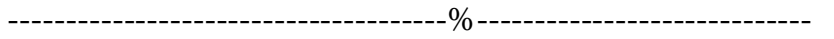 } \\
\hline Jagung Kuning & 44,00 & 43,00 & 43,00 & 42,00 \\
\hline Bekatul & 20,00 & 19,00 & 17,00 & 16,00 \\
\hline Tepung Ikan & 4,00 & 4,00 & 4,00 & 4,00 \\
\hline PMM & 5,00 & 5,00 & 5,00 & 5,00 \\
\hline Bungkil Kedelai & 20,00 & 20,00 & 20,00 & 20,00 \\
\hline MBM & 6,00 & 6,00 & 6,00 & 6,00 \\
\hline Tepung Wortel & 0,00 & 2,00 & 4,00 & 6,00 \\
\hline Premix & 1,00 & 1,00 & 1,00 & 1,00 \\
\hline Jumlah & 100,00 & 100,00 & 100,00 & 100,00 \\
\hline \multicolumn{5}{|l|}{ Kandungan Nutrisi } \\
\hline Protein Kasar $(\%)$ & 23,09 & 23,08 & 23,03 & 23,03 \\
\hline Energi Metabolis (Kkal/Kg) & $2.999,32$ & $2.990,79$ & $2.989,59$ & $2.981,06$ \\
\hline Serat Kasar $(\%)$ & 11,25 & 11,29 & 11,15 & 11,19 \\
\hline Lemak Kasar (\%) & 3,94 & 3,87 & 3,74 & 3,67 \\
\hline $\mathrm{Ca}(\%)$ & 1,49 & 1,50 & 1,50 & 1,51 \\
\hline $\mathrm{P}(\%)$ & 0,80 & 0,80 & 0,77 & 0,76 \\
\hline Vitamin A (\%) & 0,12 & 0,22 & 0,32 & 0,41 \\
\hline Betakaroten (\%) & 0,01 & 0,17 & 0,33 & 0,50 \\
\hline
\end{tabular}

Tabel 3. Komposisi dan Kandungan Nutrisi Ransum Perlakuan Fase finisher

\begin{tabular}{|c|c|c|c|c|}
\hline Bahan pakan & T0 & $\mathrm{T} 1$ & $\mathrm{~T} 2$ & T3 \\
\hline & \multicolumn{4}{|c|}{ 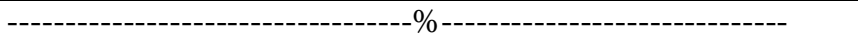 } \\
\hline Jagung Kuning & 57,00 & 55,00 & 54,00 & 54,00 \\
\hline Bekatul & 15,00 & 15,00 & 14,00 & 12,00 \\
\hline Tepung Ikan & 4,00 & 4,00 & 4,00 & 4,00 \\
\hline PMM & 4,00 & 4,00 & 4,00 & 4,00 \\
\hline Bungkil Kedelai & 15,00 & 15,00 & 15,00 & 15,00 \\
\hline MBM & 4,00 & 4,00 & 4,00 & 4,00 \\
\hline Tepung Wortel & 0,00 & 2,00 & 4,00 & 6,00 \\
\hline Premix & 1,00 & 1,00 & 1,00 & 1,00 \\
\hline Jumlah & 100,00 & 100,00 & 100,00 & 100,00 \\
\hline \multicolumn{5}{|l|}{ Kandungan Nutrisi } \\
\hline Protein Kasar $(\%)$ & 19,57 & 19,61 & 19,60 & 19,56 \\
\hline Energi Metabolis (Kkal/Kg) & $3.062,50$ & $3.047,52$ & $3.038,50$ & $3.037,30$ \\
\hline Serat Kasar $(\%)$ & 10,45 & 10,67 & 10,72 & 10,57 \\
\hline Lemak Kasar (\%) & 3,57 & 3,55 & 3,47 & 3,35 \\
\hline $\mathrm{Ca}(\%)$ & 1,44 & 1,44 & 1,45 & 1,45 \\
\hline $\mathrm{P}(\%)$ & 0,62 & 0,63 & 0,63 & 0,60 \\
\hline Vitamin A (\%) & 0,14 & 0,23 & 0,33 & 0,43 \\
\hline Beta karoten $(\%)$ & 0,01 & 0,17 & 0,33 & 0,50 \\
\hline
\end{tabular}


$\begin{array}{ccc}\text { Rancangan } & \text { percobaan } & \text { yang } \\ \text { digunakan adalah } & \text { Rancangan } & \text { Acak }\end{array}$ Lengkap dengan 4 perlakuan ransum dan diulang 6 kali sehingga terdapat 24 unit. Setiap ulangan terdiri dari 6 ekor ayam. Perlakuan dalam penelitian ini yaitu sebagai berikut :

T0 : Ransum tanpa tepung wortel

T1 : Ransum dengan tepung wortel $2 \%$

T2 : Ransum dengan tepung wortel $4 \%$

T3 : Ransum dengan tepung wortel $6 \%$

Data yang diperoleh dianalisis ragam pada taraf 5\% untuk menguji perbedaan antar perlakuan dilakukan $\mathrm{Uji}$ Jarak Berganda Duncan (Gaspersz,1996). Data mengenai pigmentasi kulit karkas diperoleh dengan menggunakan Skala Numerik dan Skala Mutu Hedonik (Soekarto,1985) dan untuk mengetahui pengaruh perlakuan terhadap pigmentasi kulit karkas ayam broiler dilakukan uji Kruskal-Wallis pada taraf 5\% (Steel dan Torrie, 1993). Parameter yang diamati dalam penelitian ini meliputi kadar lemak karkas, kadar protein karkas dan pigmentasi kulit karkas.

\section{Kadar Lemak Karkas}

Kadar lemak karkas dianalisis menggunakan metode ekstraksi soxhlet (AOAC, 1990). Kertas saring dipotong dengan ukuran $15 \mathrm{~cm} \quad \mathrm{x} \quad 15 \mathrm{~cm}$. Menimbang kertas saring dan sampel sebanyak 1 gram. Memasukan sampel ke dalam kertas saring dan di beri kode kemudian di oven pada suhu $105^{\circ} \mathrm{C}$ selama 6 jam kemudian didinginkan dalam eksikator selama 15 menit. memasukan sampel ke dalam alat soxhlet yang telah terpasang dalam waterbath. Melakukan penyaringan dengan diethyl eter selama \pm 3 -4 jam (8-10 kali sirkulasi). Mengeluarkan sampel dari alat soxhlet dan diangin-anginkan hingga tidak berbau diethyl eter. Sampel kemudian di oven pada suhu $105{ }^{\circ} \mathrm{C}$ selama 2 jam. Kertas saring didinginkan dalam eksikator kemudian ditimbang. Persentase kadar lemak dihitung menggunakan perhitungan :

Persentase lemak $=\frac{\mathrm{W} 1-\mathrm{W} 2}{\mathrm{~W}} \times 100 \%$

Keterangan :

$\mathrm{W} 1=$ Kertas saring setelah oven 1

W2 = Kertas Saring setelah oven 2

$\mathrm{W}=$ Berat Sampel

\section{Kadar Protein Karkas}

Kadar protein karkas dianalisis menggunakan metode Kjedahl (AOAC, 1990). Menimbang sampel sebanyak 1 gram kemudian dimasukan ke dalam labu mikro kjedahl $100 \mathrm{ml}$ ditambahkan $\pm 0,3$ gram katalisator selenium reagent mixture dan $15 \mathrm{ml} \mathrm{H}_{2} \mathrm{SO}_{4}$. Destruksi di dalam lemari asam hingga berwarna hijau jernih kemudian didinginkan. Memasukan hasil destruksi pada alat destilasi kemudian menambahkan $40 \quad \mathrm{ml} \quad \mathrm{NaOH} \quad 45 \%$ kemudian labu di bersihkan dengan aquades dan kran penutup corong ditutup. Membuat larutan penangkap menggunakan tabung erlenmeyer $250 \mathrm{ml}$ kemudian diisi dengan $20 \mathrm{ml}$ asam borat $4 \%$ dan menambahkan 2 tetes indikator MR+MB.

Destilasi diakhiri sampai larutan penangkap berubah warna dari ungu menjadi hijau. titrasi hasil destilasi menggunakan $\mathrm{HCl} 0,1 \mathrm{~N}$ hingga terjadi perubahan warna.

$$
\text { Kadar Protein Kasar }=\frac{(\mathrm{ml} \text { titran }) \times \mathrm{N} \mathrm{HCl} \times 0,014 \times 6,25}{\mathrm{X} \text { gram sampel }} \times 100 \%
$$




\section{Pigmentasi Warna Karkas}

Pigmentasi warna karkas dinilai secara visual oleh 7 panelis terlatih dengan menggunakanmetode skoring. Skor warna terdiri dari 5 skor dengan kriteria : 1 (sangat kuning), 2 (Kuning), 3 (Agak Kuning), 4 (Putih Kekuningan), 5 (putih). Panelis memberikan penilaian sesuai dengan petunjuk yang diberikan (Kartika $e t$ al., 1988).

\section{Income over feed and cost (IOFC)}

IOFC dihitung berdasarkan selisih total pemasukan dengan biaya pakan selama pemeliharaan ayam broiler.

\section{HASIL DAN PEMBAHASAN}

\section{Persentase Lemak Karkas}

Tabel 4. menunjukan data rerata persentasi lemak karkas, protein karkas, pigmentasi kulit karkas dan Income over feed and cost (IOFC).

Tabel 4. Rataan Persentase kadar lemak karkas, protein karkas, pigmentasi kulit karkas dan IOFC

\begin{tabular}{lcccc}
\hline \multirow{2}{*}{ Parameter } & \multicolumn{4}{c}{ Perlakuan } \\
\cline { 2 - 5 } & T0 & T1 & T2 & T3 \\
\hline Lemak karkas (\%) & 2,14 & 2,27 & 1,62 & 1,65 \\
Protein karkas (\%) & $23,33^{\mathrm{a}}$ & $23,14^{\mathrm{a}}$ & $22,63^{\mathrm{b}}$ & $22,15^{\mathrm{c}}$ \\
Pigmentasi kulit karkas & 4,10 & 3,80 & 4,00 & 3,60 \\
IOFC (Rp) & 9.798 & 9.302 & 11.108 & 8.580 \\
\hline
\end{tabular}

* Berbeda nyata $(\mathrm{P}<0,05)$

${ }^{\text {abc }}$ Superskrip yang berbeda pada baris yang sama menunjukan perbedaan yang nyata

Rataan persentase kadar lemak yang tertera pada Tabel 4 menunjukan bahwa penggunaan tepung wortel dalam ransum tidak berpengaruh secara nyata $(\mathrm{P}>0,05)$ terhadap persentase kadar lemak karkas. Rata-rata persentase lemak daging yaitu $1,62 \%$ - 2,27\%. Rataan dari seluruh perlakuan yaitu $1,92 \%$. Hal ini diduga karena adanya pengaruh $\mathrm{Ca}$ dalam metabolisme lemak. Menurut penelitian Mentari et al. (2014) bahwa terdapat interaksi antara lemak dan kalsium karena metabolisme lemak dapat dipengaruhi oleh keberadaan Ca. Tingginya kandungan $\mathrm{Ca}$ dalam daging akan menyebabkan metabolisme lemak semakin meningkat yang diakibatkan karena proses penyabunan. Ditambahkan oleh Nisa (2010) bahwa mineral Ca merupakan satu faktor yang mempengaruhi proses penyabunan dan menyebabkan lemak terbuang sehingga deposisi lemak dalam daging menjadi rendah.
Menurut Maryuni dan Wibowo (2005) penimbunan lemak dipengaruhi oleh komposisi ransum anatara lain tingkat energi dalam ransum, perbandingan energi protein dan kadar lemak ransum. Kadar lemak dalam ransum akan berpengaruh terhadap penimbunan lemak ayam pedaging. Menurut Leclercq dan Witehead (1988) yang dikutip oleh Mahfudz et al. (2009) menyatakan bahwa lemak abdominal dan lemak karkas memiliki hubungan korelasi positif, yaitu apabila lemak abdominal meningkat maka lemak karkas juga akan meningkat. Meliandasari et al.(2013) deposisi lemak ayam broiler umumnya disimpan dalan bentuk lemak di rongga perut dan dibawah kulit.

\section{Persentase Protein Karkas}

Berdasarkan perhitungan analisis statistiks, diketahui bahwa perlakuan pemberian tepung wortel dalam ransum 
memberikan pengaruh nyata $(\mathrm{P}<0,05)$ menurunkan kadar protein daging. Uji lanjut menggunakan Duncan's New Multiple Range Test (DMRT) pengaruh perlakuan menunjukan bahwa perlakuan $\mathrm{T}_{0}$ (kontrol)tidak berbeda nyata dengan perlakuan $\mathrm{T}_{1}$ (2\% tepung wortel), tetapi berbeda nyata terhadap perlakuan $\mathrm{T}_{2}(4 \%$ tepung wortel) dan $\mathrm{T}_{3}$ (6\% tepung wortel). Rata-rata persentase protein daging disajikan pada tabel 3. yaitu 22,15\% $23,33 \%$. Kadar protein daging yang semakin menurun seiring dengan peningkatan pemberian tepung wortel dalam ransum, diduga karena kalsium $(\mathrm{Ca})$ yang terdapat dalam wortel merupakan kalsium dalam bentuk ion bebas. Ca dalam bentuk ion bebas berperan sebagai aktivator enzim calcium activated neutral protease (CANP) yang bersifat mendegradasi protein, sehingga sintesis protein menjadi berkurang.

Menurut Maharani et al. (2013) kemampuan deposisi protein dalam daging berkorelasi negatif dengan kalsium daging. Mekanisme hubungan kalsium daging dengan deposisi protein adalah adanya aktivitas enzim protease dalam daging disebut calcium activated neutral protease (CANP). Aktivitas CANP tergantung pada asupan kalsium dalam bentuk ion bebas berperan sebagai aktivator, karena makin tinggi asupan kalsium, maka makin tinggi pula aktivitas CANP yang bersifat degradatif terhadap protein, akibatnya protein yang terdeposisi berkurang (rendah).

Menurut Suthama et al. (2010) bahwa deposisi protein ke dalam daging sangat penting untuk menentukan kualitas bobot karkas. Konsumsi protein dan keseimbangan asam amino merupakan faktor yang dapat mendukung deposisi protein dalam daging.

\section{Pigmentasi Kulit Karkas}

Berdasarkan perhitungan analisis statistiks, diketahui bahwa perlakuan memberikan pengaruh tidak nyata $(\mathrm{P}>0,05)$ terhadap pigmentasi kulit karkas. Rerata skor pigmentasi kulit karkas yaitu 3,6 (agak kuning) - 4,1 (putih kekuningan). Hal ini diduga karena tipe karotenoid yang berperan penting dalam peningkatan pigmentasi kulit karkas yaitu xantofil, sedangkan tipe karotenoid dalam tepung wortel adalah beta karoten. Menurut Wiradimadja (2007) tipe dan jumlah pigmen karotenoid yang dikonsumsi oleh unggas menjadi faktor utama yang mempengaruhi pigmentasi. Berdasarkan penelitian Vendrell et al. (2001) xantofil dan canthaxanthin memiliki efektivitas yang baik dalam meingkatkan pigmentasi warna kuning telur dan kulit karkas ayam broiler. Jenis pigmen berupa lutein dan canthaxanthin yang terdapat dalam pakan secara efektif berperan untuk meningkatkan pigmentasi kuning pada kulit karkas broiler.

Karotenoid tipe beta karoten cenderung kurang memberikan pigmentasi, sedangkan xantofil lebih baik dalam menghasilkan pigmentasi kuning pada ayam pedaging dan telur. Kandungan pigmen dalam ransum yang dikonsumsi akan secara proposional mempengaruhi pigmentasi pada ayam pedaging. (Lesson dan Summers, 2005). Menurut Samudera dan Arief (2008) bahwa pigmen yang diperoleh dari pakan akan terakumulasi di jaringan, selanjutnya akan terabsorbsi dalam darah dan diedarkan keseluruh tubuh yang selanjutnya memberikan efek pigmentasi pada warna kulit karkas.

\section{Income Over Feed and Cost (IOFC)}

Nilai income over feed and cost (IOFC) tertinggi diperoleh dari perlakuan 
T2 dengan penggunaan tepung wortel $4 \%$. Hal ini menunjukan bahwa penggunaan tepung wortel dalam ransum memberikan keuntungan lebih besar dibandingkan dengan ransum kontrol. Nilai IOFC yang tinggi akan baik, karena menunjukan keuntungan yang tinggi pula dari dari suatu usaha peternakan. Menurut Rasyaf (2011), semakin tinggi nilai IOFC akan semakin baik, karena tingginya IOFC berarti penerimaan yang didapat dari hasil penjualan ayam juga tinggi.

Harga ransum dengan penggunaan tepung wortel lebih murah dibandingkan dengan ransum kontrol. Hal ini disebabkan karena harga wortel $(1500 / \mathrm{kg})$ yang lebih murah dibandingkan dengan harga bekatul $(2900 / \mathrm{kg})$. Tingginya harga ransum dapat mempngaruhi nilai IOFC, karena berarti meningkatkan biaya pengeluaran. Selain itu, nilai IOFC juga dipengaruhi oleh jumlah konsumsi ransum dan bobot akhir ayam. Yahya (2003) menyatakan bahwa konsumsi ransum berperan dalam menentukan biaya pengeluaran untuk ransum ayam yang dibutuhkan selama pemeliharaan, sedangkan bobot akhir tubuh ayam merupakan komponen penyusun dari nilai penerimaan hasil penjualan ayam.

\section{KESIMPULAN}

Penggunaan tepung wortel dalam ransum hingga level 6\% belum mampu memperbaiki kualitas karkas. Kandungan Ca dalam wortel berupa ion bebas berperan sebagai aktivator enzim CANP yang dapat menurunkan kadar protein daging. Karotenoid yang dominan dalam wortel berupa beta karoten sehingga belum efektif dalam meningkatkan warna kulit karkas. Penggunaan tepung wortel dalam ransum dapat meningkatkan nilai IOFC.

\section{DAFTAR PUSTAKA}

Asgar, A. dan D. Musaddad. 2006. Optimalisasi cara, suhu, dan lama blansing sebelum pengeringan pada Wortel. J. Hortikultura. 16(3): 245252.

Asmara, I.Y., D. Garnida dan W. Tanwiriah. 2006. Penampila Broiler yang diberi ransum mengandung tepung daun ubi jalar (Ipomoea batatas) terhadap karakteristik karkas. J. Indonesia Tropical Animal Agriculture. 32(2): 12-130.

Gaspersz, V. 1995. Teknik Analisis dalam Penelitian Percobaan. Tarsito. Bandung.

Kartika, B., P. Hastuti, dan W. Supartono. 1988. Pedoman Uji Inderawi Bahan Pangan. Pusat Antar Universitas Pangan dan Gizi. Universitas Gadjah Mada, Yogyakarta.

Leeson, S. dan J. D. Summers. 2005. Commercial Poultry Nutrition. $3^{\text {nd }}$ Edition. University Book. Canada.

Lestari, F.E.P. 2011. Persentase Karkas, Dada, Paha dan Lemak Abdomen Itik Alabio Jantan Umur 10 Minggu yang Diberi Tepung Daun Beluntas, Vitamin C Dan E dalam Pakan. Fakultas Peternakan, Institut Pertanian Bogor, Bogor. Skripsi.

Maharani, P., N. Suthama., dan H.I. Wahyuni. Massa Kalsium dan Protein Daging pada Ayam Arab Petelur yang diberi Ransum Menggunakan Azolla micrphylla. 2013. Animal Agriculture Journal. 2 (1):18-27. 
Mahfudz, L.D., F. L. Maulana, U. Atmomarsono dan T.A. Sarjana. 2009. Karkas dan Lemak Abdominal Ayam Broiler yang Diberi Ampas Bir dalam Ransum. Seminar Kebangkitan Peternakan. Pemberdayaan Peternakan Berbasis Sumber Daya Lokal untuk Ketahanan Pangan Berkelanjutan. Semarang. 596-605.

Maryuni, S. S. dan C. H. Wibowo. 2005. Pengaruh Kandungan Lisin dan Energi Metabolis dalam Ransum yang Mengandung Ubikayu Fermentasi terhadap Konsumsi Ransum dan Lemak Ayam Broiler. J. Indon.Trop. Anim. Agric. 30(1): 2633.

Meliandasari, D., B. Dwiloka., E. Suprijatna. 2015. Optimasi daun Kayambang (Salvinia molesta) untuk penurunan kolesterol daging dan peningkatan kualitas asam lemak esensial. Jurnal Aplikasi Teknologi Pangan. 4 (1): 22-28.

Mentari, A.S., L.D. Mahfudz dan N. Suthama. 2014. Massa protein dan lemak daging pada ayam Broiler yang diberi tepung Temukunci (Bosenbergia pandurata ROXB.) dalam ransum. Animal Agriculture Journal. 3(2): 211-220 .

Nisa, T. K. 2010. Pengaruh Perbedaan Aras Protein dan $\mathrm{Ca}$ ansum terhadap Daya Cerna Lemak dan Warna Hati pada Burung Puyuh Betina Periode Grower. Fakultas Peternakan Universitas Diponegoro, Semarang. Skripsi.

Rasyaf, M. 2011. Panduan Beternak Ayam Pedaging. Cetakan IV. Penebar Swadaya. Jakarta.
Samudera, R dan A. Hidayatullah. 2008. Warna kulit, lemak abdomen dan lemak karkas Itik Alabio (Anas plathyrhincos Borneo) jantan akibat pemberian Azolla dalam ransum. Animal Production. 10(3): 164-167.

Soekarto, S. T. 1985. Penilaian Organoleptik. Untuk Industri Pangan dan Hasil Pertanian. Bharatara Karya Aksara. Jakarta.

Steel, R.G. D dan J. H. Torrie. 1993. Prinsip dan Prosedur Statistika. Suatu Pendekatan Biometrik. PT. Gramedia Pustaka Utama Jakarta.

Suthama, N., H. I. Wahyuni, dan I. Mangitsah. 2010. Laju pertumbuhan berdasarkan degradasi protein tubuh pada ayam Kedu dipelihara ex situ. Prosiding Seminar Nasional Tentang Unggas Lokal ke IV. Semarang 7 Oktober 2010. Fakultas Peternakan Universitas Diponegoro, Semarang. Hal. 138-146.

Vandrell, A.M.P., J. M. Hernandez., L. Llaurado., J. Schierle., J. Brufau. 2001. Influence of source and ratio of Xantofilpigments on Broiler Chicken pigmentation and performance. J. Poultry Science.80. 320-326.

Wiradimadja, R. 2007. Dinamika Status Kolesterol Pad Puyuh Jepang (Coturnix coturnix japonica) yang Diberi Daun Katuk (Sauropus androgynus, L. Merr) dalam Ransum. Pascasarjana Institut Pertanian Bogor, Bogor. Disertasi.

Yahya, A. 2003. Pengaruh Penambahan Saccharomyces cerevisiae dalam Ransum terhadap Pertumbuhan Broiler. Fakultas Pertanian. Universitas Lampung. Skripsi. 